CENTRO UNIVERSITÁRIO DE BRASÍLIA - UNICEUB

PROGRAMA INSTITUCIONAL DE BOLSAS DE INICIAÇÃO CIENTÍFICA (BOSISTA $\mathrm{PIC/JÚNIOR)}$

A PAZ NA ESCOLA: UM TRABALHO DE INTERVENÇÃO

BRASÍLIA

2020 


\section{A PAZ NA ESCOLA: UM TRABALHO DE INTERVENÇÃO}

Relatório Final de pesquisa a ser apresentado à Assessoria de PósGraduação e Pesquisa como requisito para conclusão do Programa de Iniciação Científica do UniCEUB, ciclo 2019/2020.

\section{BRASÍLIA}




\section{RESUMO}

Esta pesquisa pretendeu contribuir para a Cultura da Paz na escola e, consequentemente, ao combate à violência escolar, tomando como referência uma escola pública, em Brasília-DF. Foi desenvolvida em seu segundo ano, após terem sidos verificados os resultados positivos do primeiro ano. Nestes dois anos, tratou de uma pesquisa-ação, com a utilização de grande abrangência de atividades relacionadas à paz na escola, desde rodas de conversa folhetos sobre a Paz, participação da Semana da Consciência Negra, concursos, dentre outros. A violência na escola, atualmente, constitui um problema social e, em parte, é responsável pela evasão escolar, pelo afastamento de professores e/ou licença médica, causada por doenças psicossomáticas, como o estresse, pelo baixo rendimento dos alunos. A abordagem metodológica da pesquisa foi a pesquisa-ação, ou de intervenção. O cenário escolhido para a pesquisa foram os anos finais do Ensino Fundamental II. Todos os alunos do turno escolhido foram atingidos pelo processo de continuidade da pesquisa. O primeiro semestre ocorreu conforme o previsto, mas, em seu segundo semestre, devido à Covid19 , o projeto teve que ser desenvolvido online, pelo Instagram. As reuniões com o grupo de pesquisa foram realizadas semanalmente via o google meet. Foram feitos os concursos: música pela paz, criação de brinquedos recicláveis para doação, cartazes sobre como ser solidário durante a pandemia e o desenvolvimento de boas ações, durante todo o semestre escolar. Foi realizado o pré-teste no início do trabalho. Como instrumento foi utilizado um questionário semiestruturado. Após passados os dias iniciais da suspensão da pesquisa, devido à pandemia, iniciou-se a discussão de como dar continuidade a ele, que tinha características presenciais. Foi aí que surgiu a ideia da utilização do Instagram para a realização dos concursos, todos voltados para a paz na escola. Primeiro era feito um pequeno folheto, de cada um dos quatro concursos realizados, e colocado na rede social, explicando todo o concurso e sua premiação que seria feita com caixas de bombons. Os concursos iniciaram-se de forma tímida, mas os seus participantes logo ultrapassaram os três primeiros colocados. Os alunos postavam no Instagram as tarefas realizadas. Diretor, coordenador e professores também se envolveram nas atividades. A instituição passava por um momento muito sério de adaptação ao novo sistema de ensino, com aulas online, mesmo assim conseguiu-se obter bons resultados e criar um novo tipo de ação dentro da pesquisa. Esta pesquisa, ao lado de seu objetivo principal que foi a contribuição pela paz na escola, gerou um resultado secundário, a criatividade para a sua continuidade, a realização de forma online. Em seu pós-teste foi verificado que, $71,4 \%$ dos alunos que o responderam, tiveram conhecimento dos concursos e que $85,7 \%$ disseram acreditar que ele possa contribuir com a paz na escola. A Lei de Diretrizes e Bases da Educação 1996 enfatiza a necessidade de os professores cultivarem os valores éticos e morais para propiciar oportunidades reais para que os alunos estejam permanentemente em busca da construção de sua cidadania.

Palavras-chave: Violência Escolar. A paz na escola. Intervenção à violência. 
SUMÁRIO

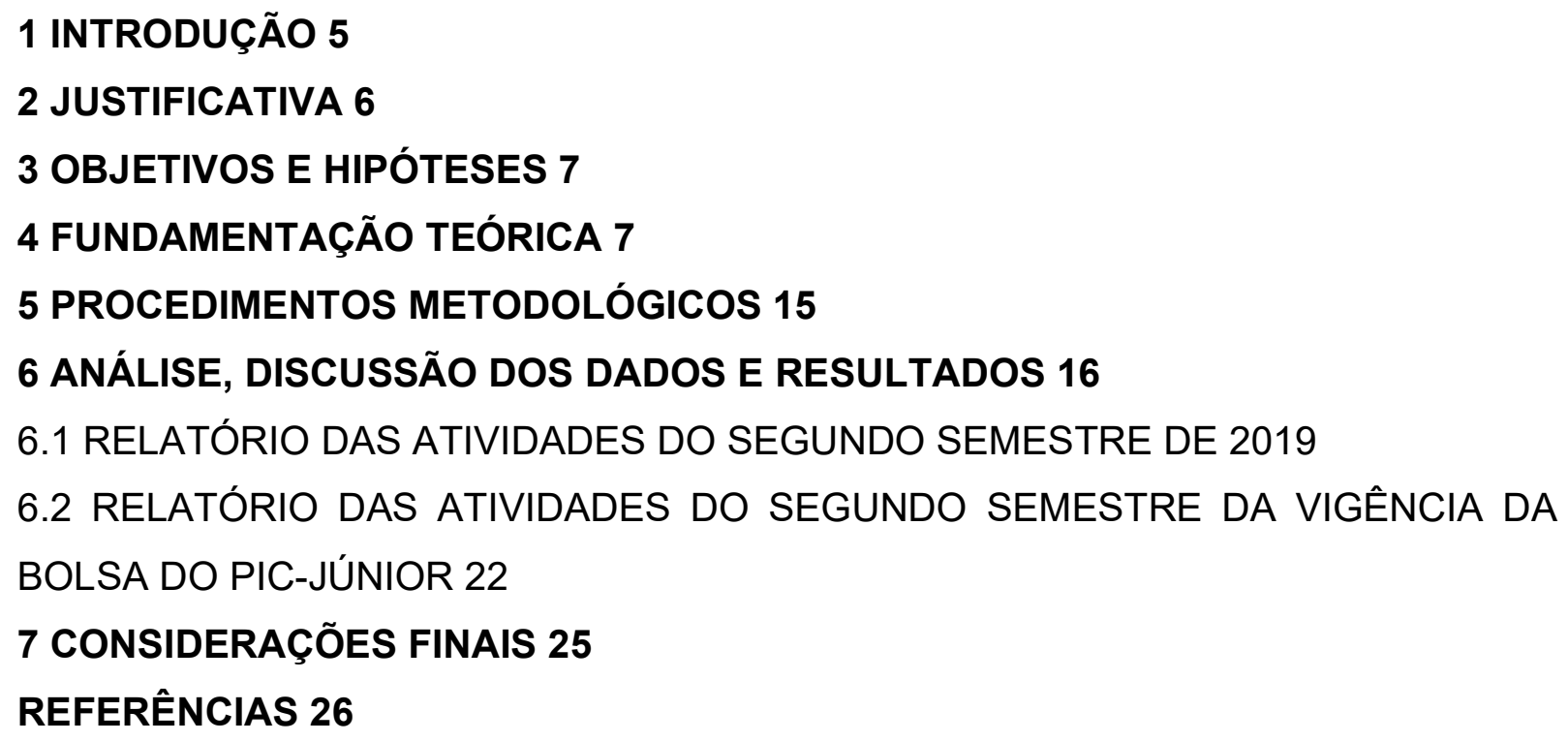




\section{INTRODUÇÃO}

Este trabalho teve como objetivo de pesquisa verificar a influência da interferência no combate à violência em uma instituição pública de ensino da Asa Norte, na Região Administrativa de Brasília-DF e procurou, objeto principal desta pesquisa, intervir no fenômeno da violência em suas várias dimensões, a saber, pedagógica, simbólica, física e material, praticada e sofrida por alunos, professores e corpo técnico, por meio de atividades e mensagens relacionadas à paz e ao combate da violência.

A violência na escola, atualmente, constitui um problema social, considerada um dos principais males da sociedade. Em parte, é responsável pela evasão escolar, pelo afastamento de professores (licença médica), causada por doenças psicossomáticas (estresse), pelo baixo rendimento dos alunos, enfim, pelo medo e insegurança que acometem as escolas na maioria das regiões do país.

Casos de violência ocorrem a todo instante no Brasil e no Mundo, como o ocorrido em outubro de 2017, em que um aluno do $8^{\circ}$ ano do Ensino Fundamental de uma escola particular, localizada em Goiânia, atirou contra outros estudantes de sua turma, deixando 2 mortos e 4 feridos. O delegado responsável pelo caso afirmou que o atirador estava motivado, segundo ele, pelo bullying causado a ele por um colega específico, e que se inspirou, também em outras tragédias (JORNAL NACIONAL, 2017).

A violência é um aspecto da sociedade há muito presente. Contudo, nas últimas décadas, sua banalização, por diversos meios, tem aproximado essa realidade de crianças e de adolescentes. Muito presente na mídia, as manifestações de agressão em escolas, de simples agressões a tentativas de homicídio, representam, dentre muitas falhas na sociedade, o enfraquecimento do símbolo de autoridade (FONTES, 2010).

Trata-se, portanto, de um problema da humanidade que, dialeticamente, ao mesmo tempo em que é causa, é também consequência, com profundos reflexos no 
ambiente escolar. Assim, vive-se um ciclo vicioso onde a violência urbana fomenta a violência familiar que, por sua vez, alimenta a violência na escola.

Em 2013 já se divulgava que “44\% dos professores da rede de ensino básico já haviam sofrido algum tipo de violência, sendo as mais comuns as verbais (39\%) e as de assédio moral (10\%) (ESTADÃO, 2017).

Diante da situação de que há uma infinidade de diagnósticos sobre a questão da violência na escola, inclusive com propostas de ação, este trabalho, ao contrário, pretendeu dar a sua parcela de contribuição no combate à violência, desenvolvendo ações que pudessem minimizar o problema. A finalidade trabalho, portanto, foi, durante um ano escolar, aplicar medidas no combate à violência na escola e verificar a eficiência dessas medidas na resolução dos problemas de violência.

\section{JUSTIFICATIVA}

A escola e seus atores têm assumido até então a postura de vítimas, alheios ao fenômeno, muitas vezes na esperança de que a sociedade e suas instâncias (polícia e justiça) sejam responsabilizadas, eximindo-os assim dessa obrigação. No entanto, não se concebe um curso de formação de futuros profissionais da educação, que irão atuar na rede particular e pública de ensino, alijado do problema. O presente trabalho pretendeu promover uma discussão-reflexão-ação para além da formação didáticopedagógica durante o processo de formação do professor. Pretendeu-se discutir o tema de forma direta, clara e objetiva e, ao mesmo tempo, após essa diagnose, ser capaz de algumas ações que possam colaborar para a solução do problema da violência na escola.

A proposta deste trabalho foi de continuidade de um projeto anterior, sobre o mesmo tema e mesma metodologia, tendo como pressuposto a possibilidade de contribuir para o processo de superação da relação violência-escola. Acredita-se que, como resultado deste trabalho, possam ser sugeridas alternativas de soluções para escolas de outras regiões de Brasília.

O problema desta pesquisa foi o seguinte questionamento: É possível com um ano ou mais de intervenção em uma escola, conseguir contribuir favoravelmente no sentido de aumentar a paz na escola? 


\section{OBJETIVOS E HIPÓTESES}

O objetivo geral deste trabalho foi, durante um ano escolar, aplicar medidas no combate à violência na escola e verificar a eficiência dessas medidas na resolução dos problemas da escola, neste aspecto. Este trabalho já foi executado durante um ano escolar, mas se verificou que o tempo foi insuficiente para se conseguir um melhor resultado.

Os objetivos específicos são:

- Diagnosticar, a partir dos resultados do projeto anterior, os problemas de violência da escola ainda existentes, em um pré-teste, às ações a serem implementadas durante mais um ano letivo;

- Propor ações durante o desenvolvimento do projeto, a fim de continuar amenizando as situações de violência na escola;

- Verificar o resultado das ações implementadas

Ressalta-se que, por ser este trabalho uma pesquisa de cunho qualitativo, não há obrigatoriedade da elaboração de hipóteses, uma vez que promove a oportunidade, inclusive, do surgimento de novas hipóteses durante o trabalho, podendo ter seu curso alterado, desde que seja para se obter melhores resultados, atingindo assim seus objetivos. Mesmo assim, levantou-se algumas hipóteses prováveis que se esperou sejam confirmadas ao final do trabalho:

- É possível conhecer sobre a violência escolar por meio dos alunos;

- O trabalho pedagógico realizado com ações e mensagens sobre "a paz na escola" poderá contribuir na solução de alguns problemas de violência e estabelecer novas relações sociais;

- O trabalho de prevenção e enfrentamento à violência poderá ser melhorado após mais um ano de projeto.

\section{FUNDAMENTAÇÃO TEÓRICA}

O tema violência sempre foi e, infelizmente, ainda será por muito tempo motivo de investigação científica. A comunidade científica busca explicações sociológicas, 
antropológicas, filosóficas, psicológicas, econômicas; todos os setores organizados da sociedade procuram justificativas e soluções para reprimir a violência inerente ao ser humano. Além do mais, a questão sobre a violência e suas diferentes manifestações na sociedade brasileira tem-se multiplicado e diversificado enormemente nos últimos anos, especialmente a partir dos anos 1980.

O que se entende por violência? Por violência, segundo o Dicionário do Pensamento Marxista (apud GUIMARÃES, 2008, p. 91), entende-se

\begin{abstract}
a intervenção física de um indivíduo ou grupo contra outro indivíduo ou grupo (ou também contra si mesmo). Para que haja violência é preciso que a intervenção física seja voluntária. [...] a intervenção física, na qual a violência tem por finalidade destruir, ofender e coagir [...]. A violência pode ser direta ou indireta. É direta quando atinge de maneira imediata o corpo de quem sofre. É indireta quando opera através de uma alteração do ambiente físico no qual a vítima se encontra [...] ou através da destruição, da danificação ou da subtração dos recursos materiais. Em ambos os casos, o resultado é o mesmo: uma modificação prejudicial do estado físico do indivíduo ou do grupo que é o alvo da ação violenta.
\end{abstract}

De acordo com Waiselfisz e Maciel (2003), conceituar violência não é tarefa fácil. Além de sua amplitude, complexidade e ambiguidade, duas questões tornam ainda mais difícil sua conceituação. A primeira delas diz respeito ao fato de que o termo violência se apresenta como um significante cujos significados são histórica e culturalmente construídos. A segunda questão está associada ao fato de que o mesmo termo pode referir-se a situações marcadamente diversificadas. Em pesquisa realizada pela UNESCO, a violência pode ser considerada como parte da própria condição humana, manifestando-se de acordo com arranjos societários de onde emerge.

Segundo Costa (2007), a violência é o emprego desejado de agressividade com fins destrutivos. Agressões físicas, brigas, conflitos podem ser expressões de agressividade humana, mas não necessariamente expressões de violência. $\mathrm{Na}$ violência, a ação é traduzida como violenta pela vítima, pelo agente ou pelo observador e ocorre quando há desejo de destruição.

Vive-se atualmente uma crise mundial em que a violência tem sido o principal instrumento dos seres humanos para enfrentar todos seus problemas sociais, profissionais, financeiros e até afetivos. Segundo a Teoria da Complexidade de Morin (2015, p. 17-19, grifos do autor): 
À primeira vista, a complexidade é um tecido (complexus: o que é tecido em conjunto) de constituintes heterogêneos inseparavelmente associados: coloca o paradoxo do uno e do múltiplo. Na segunda abordagem, a complexidade é efetivamente o tecido de acontecimentos, ações, interações, retroações, determinações, acasos, que constituem o nosso mundo fenomenal. Mas então a complexidade apresenta-se com os traços inquietantes da confusão, do inextricável, da desordem, da ambigüidade, da incerteza... Daí a necessidade, para o conhecimento, de pôr ordem nos fenômenos ao rejeitar a desordem, de afastar o incerto, isto é, de selecionar os elementos de ordem e de certeza, de retirar a ambigüidade, de clarificar, de distinguir, de hierarquizar... Mas tais operações, necessárias à inteligibilidade, correm o risco de a tornar cega se eliminarem os outros caracteres do complexus; e efetivamente, como o indiquei, elas tornam-nos cegos.

Essa cegueira social coloca-nos literalmente numa postura comportamental tão grave e perigosa quanto aquela (no sentido literal) cuja falta do sentido da visão induz à perda total ou parcial da realidade social. Essa complexidade é tão grave e comprometedora que, na maioria das vezes, restringe-se a discorrer sobre o tema, publicar belos artigos academicamente corretos sem, no entanto, efetivamente ousar iniciativas mais concretas. Sabe-se, no entanto, que existem vários tipos de cegueira, dependendo do grau e do tipo de perda da visão. Neste momento histórico, vivencia-se uma visão reduzida, ou seja, a cegueira parcial ou o daltonismo social em relação aos problemas da violência.

A Culturanálise de Grupos (CARVALHO, 1990) e a Teoria do Imaginário (G. Durand, 2012), Yves Durand, (1980), Michel Foucault (1993) são algumas das teorias já desenvolvidas para explicar e ou justificar as representações simbólicas que permeiam os movimentos corporais ou gestos. A fisiologia, inclusive, já provou que o corpo humano aglutina sentimentos, pensamentos, atuação e ação ao movimento corporal. Ao passo que se move, o ser humano percebe o mundo em que vive e pode reagir pelo instinto (defesa ou ataque) ou pelo afeto (carinho, solidariedade etc.). Aristóteles (apud GOLEMAN, 2011) já dizia que "qualquer um pode zangar-se - isso é fácil. Mas zangarse com a pessoa certa, na medida certa, na hora certa, pelo motivo certo e da maneira certa - não é fácil". A civilização, em determinados momentos históricos, assume características de barbárie e, atualmente, com o advento da globalização, vive um 
momento de impasse: a sociedade se organiza para enfrentar a violência de forma definitiva ou não haverá prisões suficientes no planeta para conter todos os transgressores.

Ao traçar um quadro da violência no Brasil, Arrieta (2000, p. 94) afirma que "a história do Brasil é, sob certo aspecto, uma história social e política da violência". Lembra as repressões às lutas populares nas diferentes regiões do país, salientando que nesse processo repressivo não se economizou força, não se pouparam vidas. É importante levar em consideração, também, o poder da sociedade em geral. É nesta perspectiva que se insere o estudo sobre violência que relaciona Estado e sociedade. $O$ Estado aparece, assim, como uma instância que reflete as relações autoritárias existentes na sociedade e a maneira também autoritária de resolver seus conflitos e superar as diferenças e dificuldades nos campos econômico, social, político, cultural, assim como nas relações intersubjetivas de modo geral.

Alguns autores referem-se à família como condicionante ou antecedente de personalidades violentas, hipótese esta, objeto de ampla controvérsia, sendo rejeitada por muitos estudiosos do assunto. Em todos os grupos sociais existem famílias abusivas. Raramente, entretanto, é reconhecido que os pais podem praticar atos de violência, sendo eles considerados, muitas vezes, apenas como nervosos ou agressivos. Compreender como se estabelecem as relações dos alunos com seus familiares é ponto crucial para capacitar o profissional da educação a lidar melhor com o problema da violência.

De acordo com Candau, Lucinda e Nascimento (2001), a violência é uma realidade na qual suas manifestações intraescolares se apresentam como reflexo da violência social. Neste sentido, é um fenômeno fundamentalmente derivado, cuja dinâmica se origina na sociedade e se reflete na escola. Seu dinamismo é de fora para dentro. A marca constituída da violência seria a tendência à destruição do outro, ao desrespeito e à negação do outro, podendo a ação situar-se no plano físico, psicológico ou ético.

Arendt (2009) diz que existem diversas hipóteses para explicar as violências nas escolas, recorrendo-se a múltiplas associações com as características e atributos das vítimas e dos agressores. Segundo o autor, constata-se que gênero é um aspecto 
observado. Os meninos se envolvem mais que as meninas em situações de violência, como vítimas ou como autores. O comportamento agressivo é associado ao ciclo etário. $\mathrm{Na}$ escola reproduzem-se os estereótipos étnicos, e o tratamento discriminatório por parte dos colegas e professores pode ser evidenciado.

Por outro lado, quando se fala em violência na escola, a questão da indisciplina na sala de aula é sempre lembrada pelos professores que hoje se sentem subjugados, enfraquecidos, acuados por uma parte dos alunos. Um aluno indisciplinado pode causar sérios prejuízos no contexto escolar. Acredita-se, ademais, que a escola está vivendo uma crise de autoridade, e os professores, muitas vezes, ficam sem saber o que fazer. Tentam compreender melhor o que está ocorrendo e passam a questionar os comportamentos ou atitudes que devem adotar diante do atual quadro, na tentativa de refletir e redimensionar as relações sociais na escola.

A agressão física, simbolizada pelo estupro, pelas brigas em família, pela falta de respeito entre as pessoas, pela ruptura da liberdade e dos direitos do cidadão, pela invasão de privacidade, pela falta de solidariedade, pelo desrespeito aos direitos dos humanos: são modalidades de agressão que se caracterizam como física, psicológica, sexual e moral.

$\mathrm{Na}$ escola, infelizmente, grande parte dessas transgressões também acontece e a criança, por exemplo, que não assimilou regras básicas de convivência social, acha que tudo é permitido. Nesse sentido, Colombier, Mangel e Perdriaut (1999, p. 89) afirma que:

[...] alunos indisciplinados e mal-educados atormentam professores, e estes não apresentam condições para 'controlar a bagunça que corre solta dentro da sala de aula'. E o que é pior: não bastassem as conversinhas, os risinhos, as guerrinhas de papel, o respeito pela figura do professor passou a ser tão raro como uma nota 10 em redação.

A crise de autoridade - tanto familiar quanto educacional - inegavelmente tem suas bases na relação familiar. Perpassa o conjunto das relações nas diferentes instituições da sociedade, repercutindo de forma direta na escola a ponto de alguns professores decidirem abandonar a profissão por não saberem enfrentar o desafio.

Quando alguém se depara com a violência nas escolas analisa de formas variadas os seus efeitos, como: a frieza nas relações, a indisciplina, os confrontos 
ocultos, as diferentes formas de ameaça, a destruição do ambiente escolar, as grades e os muros erguidos. O fato já nos é conhecido, não temos a necessidade de imaginá-lo. A cena da escola como o centro da formação do pensamento da espécie humana, parece ter sido trocada pela cena de breves guerras civis, batalhas pequenas, porém visíveis a ponto de provocar um incômodo nos professores brasileiros (AQUINO, 1998).

Ainda em relação à questão da indisciplina, pode-se observar que a maioria das escolas, principalmente as públicas, parou no tempo. Não conseguiram incorporar a seu cotidiano as novas tecnologias e conteúdos aos quais os alunos têm tido acesso. Os alunos reivindicam aulas mais dinâmicas, mais criativas e com mais novidades; entretanto, a prática desenvolvida na maioria das escolas ainda está embasada na aula expositiva e no uso do giz-e-lousa. Obviamente isso não justifica o crescimento da violência; no entanto, acredita-se que possa contribuir sobremaneira para o tédio pedagógico a falta de adrenalina tão necessária às crianças e jovens em idade escolar.

Nesse sentido, compreende-se que, até pela necessidade de autodefesa, para os educadores de modo geral, a violência evidencia-se - de forma mais clara - na relação entre os alunos. Na perspectiva dos docentes, os discentes é que são violentos e geralmente os professores não se percebem promotores de atitudes de violência com relação aos alunos. É como se os professores, diretores e coordenadores pedagógicos fossem isentos de práticas violentas. Entretanto, muitas vezes colocam-se como autoritários, superiores, detentores do poder e das tomadas de decisões, ou seja, comportam-se como donos da instituição, seja ela pública ou particular.

Neste quadro de violência, a falta de indignação da população em relação ao problema, que considera apenas indisciplina por parte do aluno ou falta de autoridade por parte dos professores, diretores ou coordenadores, tem retardado a cada dia iniciativas para interromper tal situação.

Partindo da compreensão de que as contradições que perpassam o conjunto da sociedade se manifestam e se refletem no interior da escola, resolveu-se aprofundar e explicitar essas relações. De acordo com Constantini (2005), a violência explícita ou implícita no contexto escolar caracteriza-se por um comportamento ligado à agressividade física, verbal ou psicológica que é genericamente conhecido como bullying. 
Este fenômeno, ainda pouco estudado no Brasil, tem características especiais uma vez que, para ser visto como tal, necessita de algumas considerações e condições restritas ao comportamento do indivíduo no ambiente escolar. Daí sua complexidade, visto que geralmente a vítima é considerada aluno-problema com dificuldades de aprendizagem e ou baixo rendimento escolar, enquanto o aluno intimidador, provocador é considerado aluno indisciplinado. Interessante ressaltar que o bullying, tal como foi estudado em outros países (EUA, Itália, França etc.), não se restringe a conflitos normais ou brigas que ocorrem entre alunos, mas: verdadeiros atos de intimidação, preconcebidos, ameaças, que
sistematicamente, com violência física e psicológica, são repetidamente
impostos a indivíduos particularmente mais vulneráveis e incapazes de
se defenderem, o que os leva na maioria das vezes a condição de
sujeição, sofrimento psicológico, isolamento e marginalização
(CONSTANTINI, 2005, p. 69).

Já sendo um problema conhecido, porém que tem ganhado força nos últimos anos, o bullying é uma forma de violência presente em toda a sociedade, principalmente no ambiente escolar. Caracterizado como um ato agressivo, antissocial e repetitivo, sua crescente manifestação é deveras preocupante, em razão das vítimas apresentarem problemas psicológicos a curto, médio e longo prazo. Como os casos são específicos, é necessário, para sua resolução, o entendimento do contexto onde está inserido o agressor. O trabalho de um psicólogo no enfrentamento direto e prevenção do bullying vê-se indispensável no ambiente escolar (FREIRE; AIRES, 2012).

Há alguns anos atrás, a mídia divulgou amplamente o episódio do massacre de 34 estudantes na universidade Virgínia Tech, nos EUA, episódio trágico que chocou o mundo, uma vez que foi seu autor um jovem estudante que, pelas características comportamentais, físicas e emocionais, fora ou se sentira vítima de bullying. Houve outro episódio, conhecido como o "Massacre de Columbine", também nos EUA, retratado no documentário "Tiros em Columbine", do cineasta Michael Moore. Em abril de 1999, dois jovens, Eric Harris e Dylan Klebold, entraram na Columbine High School fortemente armados, assassinaram 12 colegas e uma professora, antes de acabarem com as próprias vidas. O fato chocou o mundo; talvez seja mais chocante o motivo que gerou a realização da chacina: eles eram vítimas de bullying. Não é preciso ir muito longe. No Brasil, já houve casos semelhantes de adolescentes armados em escolas, 
com desfechos trágicos. Atualmente, diversas pesquisas e programas de intervenção antibullying vêm desenvolvendo-se em países da Europa e nos Estados Unidos. Por enquanto, o Brasil restringe-se a discutir o tema, fazer palestras e quando muito, publicar artigos com objetivos meramente acadêmicos.

Uma pesquisa realizada em 11 escolas cariocas pela Associação Brasileira Multiprofissional de Proteção à Infância e à Adolescência (ABRAPIA) (LOPES NETO; SAAVEDRA, 2004), no Rio de Janeiro, revelou que $60,2 \%$ dos casos de bullying acontecem em sala de aula.

Esses dados estatísticos, bastante alarmantes, têm chamado a atenção da sociedade em geral. $O$ assassinato tem sido a principal causa de morte de adolescentes do sexo masculino em São Paulo, Rio de Janeiro, Brasília etc., e grande parte teve como cenário a sala de aula ou os pátios escolares. Daí a importância da intervenção pedagógica ainda na formação do educador. Mudar a cultura perversa da humilhação e da perseguição na escola, trabalhar insistentemente na filosofia da inclusão, na aceitação da diversidade cultural, social, intelectual, sexual etc. e na tolerância religiosa e política. É preciso atuar decisivamente no ambiente escolar, enfatizando a importância de se considerar e respeitar as diferenças individuais, resgatando valores e princípios familiares, éticos e morais e, acima de tudo, a autoestima do jovem estudante brasileiro. Acredita-se que essa responsabilidade ainda está ao alcance das instituições formadoras. Para isso, é preciso identificar o bullying e conhecer todas as estratégias de como evitá-lo.

A escola e os educadores necessitam motivar-se para prevenir a violência, especialmente aquela cometida na família e no próprio ambiente escolar. Atitudes concretas, como a melhoria da qualidade de ensino, da relação interpessoal entre professores e alunos, da integração e atenção da escola na família são aspectos relevantes que podem prevenir a violência no âmbito escolar e familiar.

Portanto, é preciso levar em consideração a emergência e a evidência dos fatos acima e considerar as determinações da Lei de Diretrizes e Bases da Educação (LDB/96) (BRASIL, 1996) e, ainda, os temas transversais (Ética, Cidadania, Educação Sexual e Desenvolvimento Sustentável) contidos nos Parâmetros Curriculares Nacionais da Educação (PCN/02) que enfatizam a necessidade dos professores 
cultivarem os valores éticos e morais ao longo do processo educacional, ressaltando informações e proporcionando situações vivenciais (oficinas, workshop, projetos, pesquisas, etc.); enfim, propiciar oportunidades reais para que os alunos estejam permanentemente em contato com as teorias e as práticas relativas ao processo de construção da cidadania. Esta foi a premissa que orientou o presente trabalho.

\section{PROCEDIMENTOS METODOLÓGICOS}

A abordagem metodológica da pesquisa foi a pesquisa-ação, de cunho qualitativo. Entretanto, também foram utilizados elementos da pesquisa quantitativa, quando foi necessária maior visibilidade numérica dos dados.

A pesquisa qualitativa, segundo Minayo (2009, p. 21-22)

se preocupa, nas ciências sociais, com um nível de realidade que não pode ser quantificado, ou seja, ela trabalha com o universo de significados, motivos, aspirações, crenças, valores e atitudes, o que corresponde a um espaço mais profundo das relações dos processos e dos fenômenos que não podem ser reduzidos à operacionalização de variáveis.

Nesse sentido, Bogdan e Biklen (apud LÜDKE; ANDRÉ, 2013, p.11-13) assinalam as características fundamentais da pesquisa qualitativa, a saber: tem o ambiente natural como sua fonte direta dos dados e o pesquisador como seu principal instrumento; os dados coletados são predominantemente descritivos; a preocupação com o processo é muito maior do que com o produto; o significado que as pessoas dão às coisas e a sua vida são focos de atenção especial pelo pesquisador.

Quanto à pesquisa-ação, Thiollent (1988, apud ZINATO; MONTENEGRO, 2004) salienta que ela promove a participação dos usuários do sistema escolar na busca de soluções a seus problemas. Tal processo supõe que os pesquisadores adotem uma linguagem apropriada. Os objetivos teóricos da pesquisa são constantemente reafirmados e afinados no contato com as situações abertas ao diálogo com os interessados, em sua linguagem popular.

Baseadas ainda nesse autor, Zinato e Montenegro (2004) enfatizam que não se trata apenas de observar ou de descrever. O problema consiste em saber como alcançar determinados efeitos, conceber objetos, organizações, práticas educacionais e 
suportes materiais com características e critérios aceitos pelos grupos interessados. Tal concepção possui uma dimensão conscientizadora.

Nesse sentido, o cenário escolhido para a pesquisa foi o Colégio Gisno, situado no Plano Piloto, Brasília, Distrito Federal. Trata-se de uma escola que possui as séries finais do Ensino Fundamental e do Ensino Médio e que, apesar de estar situado em uma área nobre do Plano Piloto, atende alunos oriundos da periferia de classes média baixa e baixa.

O período escolar escolhido, tanto da coleta de dados quanto do processo de intervenção, foi o turno vespertino, por ser o de maior disponibilidade para os alunos bolsistas. Esse turno possuía 400 (quatrocentos alunos) e todos foram atingidos pelas atividades previstas e efetivadas no período de um ano na escola.

Tanto para o pré-teste, quanto para o pós-teste (este último após a implementação das ações) foi utilizado um questionário semiestruturado que verificaram o antes e o depois do desenvolvimento das ações a fim de comparar se houve alteração das atitudes dos alunos após a intervenção. Antes, os alunos assinaram o TCLE.

O primeiro semestre ocorreu conforme o previsto (vide relatório abaixo), mas, em seu segundo semestre, devido à Covid-19, o projeto teve que ser desenvolvido online, pelo Instagram. As reuniões com o grupo de pesquisa foram realizadas semanalmente via o google meet.

Foram feitos concursos (música pela paz, criação de brinquedos recicláveis para doação, cartazes sobre como ser solidário durante a pandemia e o desenvolvimento de boas ações) durante todo o semestre escolar.

\section{ANÁLISE, DISCUSSÃO DOS DADOS E RESULTADOS}

\subsection{RELATÓRIO DAS ATIVIDADES DO SEGUNDO SEMESTRE DE 2019}

Após todas as providências junto ao Comitê de Ética do UniCEUB e aprovação do projeto, realizou-se junto à escola uma diagnose para verificar as sugestões da escola quanto ao projeto. Tal situação foi realizada, tendo em vista de que na avaliação 
do PIC, foram sugeridas atividades diferentes das do primeiro ano de vigência do projeto. A seguir serão as atividades desenvolvidas no primeiro semestre de 2019.

\section{- Resultado da Diagnose Inicial}

Responderam aos questionários 29 alunos entre 11 a 16 anos de idade, do $6^{\circ} \mathrm{e}$ $9^{\circ}$ ano. Sobre a evidência de violência na escola, 18 alunos relataram que não há violência no ambiente escolar e 15 relataram que "sim", destacando as violências verbais, físicas como as principais, que abrange brigas e bullying; em seguida o assédio, o racismo e roubos. Segundo Escolaweb (2020, p. 3), os alunos que sofrem violência ou bullying, apresentam os seguintes sinais:

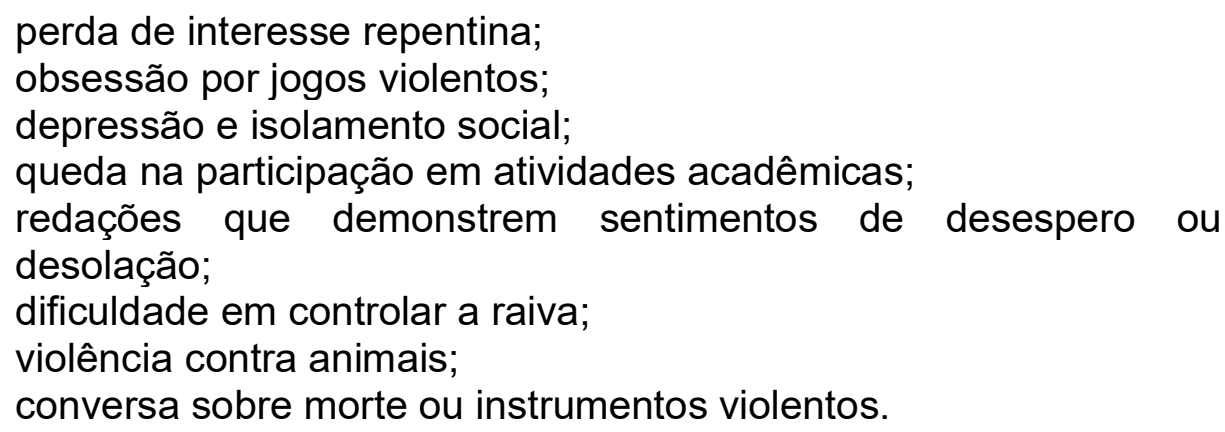

Foi perguntado se os alunos já participaram de algum ato de violência na escola, qual (ais) e se eles arrependeram: 27 alunos responderam que não participaram e 2 responderam que sim e 1 afirmou que não se arrependeu. Foi explicado que o UniCEUB tem um projeto de contribuição para a paz na escola, no Gisno, que ele já está sendo desenvolvido há um ano na escola, e foi perguntado o que poderia ser feito neste sentido: apenas 11 alunos responderam e tiveram ideias como "acho que podemos combater várias coisas como racismo, homofobia etc."; "combater o preconceito com as diferenças"; "aulas educativas, palestras e atividades em grupo"; "tem que ter mais pessoas para nos orientar"; "colocar guardas na escola", "manter os alunos ocupados com várias atividades"; e outros, como eliminar agressões e bullying e disseminar respeito. Sobre este aspecto, Escola Inteligente, 2020, p. 2) salienta que "Essa conscientização em massa funciona como uma dupla estratégia, fazendo com que aqueles que praticam a violência entendam porque não devem 
fazê-lo, e os que a sofrem, se encorajem a relatar a situação para a família e professores".

Foi perguntado, também, quais atividades desenvolvidas pelo projeto o aluno achava que havia dado certo: 11 alunos não responderam; 7 responderam que não estudavam na escola no ano anterior; e os outros 4 citaram a roda de conversa, a oficina de teatro, o concurso de dança e o debate; sobre o que não teve resultado positivo, nenhum aluno soube responder.

A última pergunta foi sobre se havia alguma sugestão para o combate à violência e 5 alunos responderam: policiamento na escola; rodas de conversa sobre o tema: Diferenças; a expulsão e advertências aos alunos que cometerem violência; projetos interdisciplinares; filmes e palestras. Segundo Escolaweb (2020, p. 1), deve-se realizar atividades, tais como: "campanhas; palestras; atividades preventivas; jogos colaborativos; vivências entre os alunos; rodas de conversa; e ações educativas", para se combater a violência na escola.

Cabe ressaltar aqui, que o projeto, em seu primeiro ano de vigência, foi premiado como Prêmio Destaque PIC Júnior e Menção Honrosa do PIBIC.

\section{- Grafitagem}

Conseguiu-se para a atividade cinco grandes madeirites e tintas para a grafitagem. Foram convidados os alunos interessados e colocados os madeirites em um local que não sujaria a escola. Entretanto, antes da grafitagem, a aluna Águeda do PIC realizou uma palestra explicando o objetivo da grafitagem, a diferença entre grafitagem e "pichação" e deu exemplos do que poderia ser desenhado nos murais. Cada painel pode ser desenhado por vários alunos.

A atividade gerou grande interesse dos alunos, que entenderam muito bem a finalidade da grafitagem, qual seja, a Paz na Escola. Segue um relatório da grafitagem, feita por um bolsista do projeto.

Usou-se pedaços de madeirites para se fazer a grafitagem com os alunos, com o tema sobre paz na escola. Foram alunos de turmas misturadas dos $6^{\circ}, 7^{\circ}$ e $8^{\circ}$ anos.

Antes da grafitagem, todos estavam reunidos em sala e a Águeda falou sobre a diferença entre grafitagem e pichação. 
Os madeirites foram colocados do lado de fora, ao ar livre, com a ajuda de algumas pessoas da escola. Durante a atividade, embora alguns alunos fizessem brincadeiras sobre pichação, eles não escreveram ofensas. Alguns ainda escreveram palavras sobre paz, e outros fizeram desenhos.

\section{- Participação da Reunião de Pais}

Foi decidida a participação da profa. Maria Eleusa Montenegro na reunião de pais, do colégio escolas, tendo em vista que se sabe que a parceria "pais e projeto" levaria a melhores resultados. Foram expostos, para esta reunião, os quadros da grafitagem. Ainda segundo Escolaweb (2020, p. 4), "a parceria entre educadores, família e sociedade é essencial para prevenir e resolver conflitos dentro e fora das salas de aula e incutir em seus alunos, crianças e adolescentes, valores como respeito, solidariedade, tolerância, ética, justiça e amizade".

$\mathrm{Na}$ reunião foi explicada a finalidade do projeto, expostas todas as atividades realizadas até o momento e lidas todas as mensagens passadas aos alunos, no ano anterior. Ao final, foi solicitado aos pais que continuassem a trabalhar em casa os valores repassados pelo projeto. Ainda sobre este assunto, Marcelos (2011, p.2) afirma que "Valores como solidariedade, humildade, companheirismo, respeito, tolerância, são pouco estimulados nas práticas de convivência social, quer seja na família, na escola, no trabalhou em local de lazer".

\section{- Atividades acerca da Consciência Negra}

Por determinação da Secretaria de Estado de Educação do Distrito Federal a conscientização sobre raça não deveria mais ser realizada apenas no Dia da Consciência Negra, mas durante o semestre letivo. Este projeto assumiu esta atividade e utilizou para isto toda a semana, onde cada turma esteve presente em um horário. Todas as turmas foram atingidas pelo trabalho sob a coordenação de duas pessoas do projeto do PIC, em cada turma. Com relação aos atos violentos, dentre eles o racismo, Stelko-Pereira e Williams (2010, p. 5, grifo das autoras) abordam que: "A configuração dos atos violentos é outro aspecto importante para ser discutido em relação à definição de violência escolar. Os atos violentos são únicos em si, pois cada um tem uma configuração em relação aos envolvidos, duração, motivos, espaço 
geográfico ocorrido, características das ações violentas, data e horário de ocorrência e desfecho".

Foram passados para os alunos dois pequenos documentários sobre o assunto e em seguida abriu-se para a discussão dos temas. Alguns coordenadores fizeram algumas perguntas durante a execução da atividade. "Crianças que sofrem quaisquer tipos de agressões devem ter consciência do seu valor para que não internalizem o tratamento recebido por alguém que as menospreze ou humilhe" (ESCOLA INTELIGENTE, 2020, p. 2).

Houve bastante participação na atividade, com depoimentos profundos por parte dos alunos. Segue um relatório dessa atividade, feita por um bolsista do projeto. As turmas em que estive presente foram as $6^{\circ} \mathrm{s}$ "A, B". Os alunos entraram em sala e assistiram aos 2 vídeos, que ao total deram 15 minutos.

$\mathrm{Na}$ hora da discussão sobre o tema, um aluno falou que na sala de aula de sua antiga escola, uma garota branca, loira, praticava várias vezes racismo com uma colega negra. Outro aluno falou que um colega era chamado de "Negueba", e disse que esse amigo se acostumou com o apelido.

As alunas da psicologia falaram sobre o termo "inhaca", presente no vídeo, que significa uma tribo de negros, e que o termo se popularizou como algo "nojento/ruim", que esse problema é comum na sociedade, até em nós mesmos, porque falamos coisas sem pesquisarmos.

- Rodas de conversa sobre a Paz na Escola - No ano anterior esta foi uma das atividades mais bem avaliadas do projeto e solicitada a sua continuidade.

Para a realização desta atividade foi solicitado oficialmente a ajuda do curso de Psicologia do UniCEUB, que disponibilizou 6 estagiários desse curso, dos últimos semestres. De acordo com Escola Inteligente (2020, p. 2), "Se você perceber que episódios de violência têm ocorrido em sua escola, talvez seja o caso de convidar um profissional especializado para auxiliar na tarefa de identificar as motivações, discutir as ações e atuar em busca de soluções". Nesta atividade foram realizadas dinâmicas, tais como: Réplica de desenho com tintas e pincéis; Caixa de Frases, dentre outras.

Após o término da dinâmica, partiu-se para um grupão, onde os alunos puderam emitir suas opiniões sobre a dinâmica e sobre o assunto. Quatro turmas foram atingidas 
pelo trabalho, que se considera muito importante na campanha pela Paz na Escola. Segundo Stelko-Pereira e Williams (2010, p. 3), o papel da escola:

Enquanto instituição de escolarização formal, a escola deve ser defendida, os processos de desenvolvimento do indivíduo que nela ocorrerem devem ser estudados, e as melhorias, buscadas, a fim de que desenvolvamos indivíduos felizes, justos, críticos e transformadores, que possam retornar à sociedade o desejo e os meios para a construção de uma sociedade mais igualitária.

Segue um relatório de uma das rodas de conversa, feita por um bolsista do projeto: a roda de conversa aconteceu dia 06/11/2019, na $8^{\circ} \mathrm{A}$, sala 2 , conduzida pela aluna de Psicologia Carol, a aluna de Ciências Biológicas Águeda e a Karla, aluna do Gisno e do PIC Júnior.

A primeira atividade consistiu na entrega de papéis para que cada aluno relatasse coisas que não gostavam de ouvir, sobre eles. Depois que colocaram o seu papel em uma caixa, esta caixa rodou entre eles, para que cada um lesse um relato escrito e discutisse o que sentiria escutando essa ofensa de alguém.

A princípio a turma estava brincalhona e levava algumas respostas na brincadeira, como por exemplo: Se te chamassem de fedorento? "Eu tomaria banho".

Em alguns papéis foram citadas frases sobre homofobia, sobre preconceitos e frases e machistas. A Águeda comentou sobre o fato de ofenderem uns aos outros diante de situações sobre gênero e padrões estéticos. O bullying apareceu no termo "quatro olhos", onde os alunos reconheceram ser errado e desagradável de se ouvir.

A segunda atividade do dia se deu em uma dinâmica com pintura; alguns alunos não quiseram participar. Entretanto, os alunos que participaram foram produtivos, entenderam que precisavam uns dos outros. Apenas uma aluna não concordou que precisava de alguém em sua vida. A Águeda novamente comentou que é importante ter amigos, que se deve ter amigos e ser amigos das pessoas e que isto torna a vida humana e o mundo melhores.

\section{- Outras atividades realizadas durante o semestre}


Os alunos do PIC Júnior e PIC, juntamente com a orientadora do projeto, reuniram-se semanalmente para tomar decisões quanto ao trabalho, avaliar as atividades realizadas e estudar textos sobre o tema.

Também, houve a participação dos alunos na reunião do Grupo de Pesquisa "Prática Pedagógica e Formação do Professor" ao qual o projeto se encontra vinculado.

Houve também a participação em congressos científicos para a apresentação do projeto e a publicação em revistas científicas sobre o seu relatório.

Intermediou-se, também, o contato dos professores da Arquitetura do UniCEUB com o GISNO, para o desenvolvimento de projetos na área Arquitetura e Educação e o pessoal desta pesquisa assistiu à apresentação de seus relatórios.

Convém ressaltar que todas as Referências utilizadas na discussão dos resultados, foram lidas e discutidas com os integrantes do PIC Júnior e PIC, durante as reuniões semanais do grupo. Procurou-se evitar textos muito complexos, tendo em vista que dois alunos do PIC Júnior (um bolsista e um voluntário), leram também os textos.

\subsection{RELATÓRIO DAS ATIVIDADES DO SEGUNDO SEMESTRE DA VIGÊNCIA DA BOLSA DO PIC-JÚNIOR}

O primeiro semestre ocorreu conforme o previsto, com as atividades sendo realizadas de forma presencial, mas, em seu segundo semestre, devido à Covid-19, o projeto teve que ser desenvolvido online, pelo Instagram. Após passados os dias iniciais da suspensão das aulas e, consequentemente, da pesquisa, devido à pandemia, iniciou-se a discussão de como dar continuidade a ele, que tinha apenas características presenciais. Foi aí que surgiu a ideia da utilização do Instagram para a realização dos concursos, todos voltados para a paz na escola. Primeiro era feito um pequeno folheto, de cada um dos quatro concursos realizados, e colocado na rede social (explicando todo o concurso e sua premiação que seria feita com caixas de bombons).

Os concursos iniciaram-se de forma tímida, mas os seus participantes logo ultrapassaram os três primeiros colocados. Os alunos postavam no Instagram as tarefas realizadas. A seguir, uma pequena descrição de cada um deles: 
- Concurso de música pela paz - no primeiro concurso, apesar da grande divulgação, apenas duas candidatas participaram. Tanto todo o corpo pedagógicoadministrativo do Gisno, quanto os alunos encontravam-se muito preocupados com a situação da pandemia e de como as aulas online iriam ocorrer. Então, foi considerado que duas participantes foi um bom contingente para o primeiro concurso. Conforme salientado, primeiro era colocado o anúncio no Instagram, de um quadro com todas as informações, e os alunos deveriam postar aí as suas atividades. Após o término, era combinado com eles a forma da entrega da caixa de bombom. Todas as explicações, realização das tarefas e entrega dos bombons eram postadas no Instagram (VIDE APÊNDICE).

Decidiu-me pelo concurso de música porque, conforme Platão: "Educar através da música é mais soberano, porque mais do que qualquer outra cousa, o ritmo, a harmonia terão influência no ser humano, nas mais diversas possibilidades do dia a dia. A ideia de educação musical é muito boa"... (PGL.GAL, 2020). "O simples ato de ouvir música pode produzir mudanças positivas no humor, restaurar a paz e o equilíbrio emocional, proporcionar relaxamento e facilitar a expressão de sentimentos, tais como: tristeza, raiva e luto". (SEKI, N. H.; GALHEIGO, 2009, p. 278).

- Elaboração de material reciclável para doação - As tarefas todas foram decididas em grupo e, muitas vezes, votada. Quando foi proposta esta atividade, sua escolha deveu-se a dois fatores: a criação do material reciclável (Educação Ambiental) e doação (solidariedade). Neste aspecto pode-se ler esta frase, de uma ação educativa que também elaborou e doou materiais:

O protagonismo dos estudantes, através da construção coletiva dos brinquedos e jogos cooperativos, da doação dos jogos para a Brinquedoteca Universitária, e da reorganização do espaço com um novo cantinho de jogos do "mundo social e sentimentos", auxiliou na compreensão da emergência de trabalhos mais voltados à dimensão humana do conhecimento social por meio dos jogos de convívio ou cooperativos nos espaços escolares. Ademais, contribuiu para o processo de identificação, pertencimento e ação solidária, ao vermos mais estudantes frequentando a Brinquedoteca Universitária, bem como se candidatando à vaga de estágio voluntário. (SOARES; TEIXEIRA, 2017).

Nesta atividade, a participação foi bem maior, inclusive com as classes de deficientes do Gisno que, naquele momento, estavam trabalhando com materiais 
recicláveis. Houve mais participantes que os prêmios que se tinha, mas se optou por entregar a caixa de bombom a todos os participantes. Esta foi a atividade mais emocionante da pesquisa, tendo em vista que muitos alunos deficientes decidiram presentear também alunos com deficiência. As professoras destas classes contribuíram muito com a atividade e ela deu mais dinamismo e quantidade de participantes ao concurso.

- Cartazes sobre como ser solidário durante a pandemia - No concurso o aluno poderia fazer ou uma redação sobre o assunto ou um desenho. Todos os que participaram fizeram desenhos. Sobre a importância da solidariedade, temos a citação de Construir Notícias (2020, p.1), que afirma que "a solidariedade previne a violência. Uma sociedade solidária devolve aos excluídos cidadania e condições de vida digna". Também, que "construir uma cultura da paz envolve dotar as crianças e os adultos de uma compreensão dos princípios e respeito pela liberdade, justiça, democracia, direitos humanos, tolerância, igualdade e solidariedade" (DUPRET, 2002).

Os tipos de solidariedade apresentados disseram respeito à doação de alimentos e de máscaras.

- $\quad$ Apresentar uma boa ação com colegas ou com pessoas da terceira idade Como última atividade do semestre, o concurso seria fazer uma boa ação com colegas ou com pessoas da terceira idade. Neste aspecto, tivemos boa ação apenas com pessoas da terceira idade. A importância de uma boa ação pode ser identificada nesta frase:

Sugeri que escrevessem uma mensagem para elas e fizessem um desenho. Montaríamos uma carta gigante e a enviaríamos pelo correio". Diz uma professora que teve a ideia de mandar mensagens e desenhos dos seus alunos para duas professoras que foram vítimas de racismo em Minas Gerais. (BRASIL.MEC, 2018).

A boa ação, à semelhança da solidariedade e da doação, contribui para o indivíduo veja o outro, queira ajudá-lo, dissuadindo-se de outras situações como a violência. "Construir uma cultura da paz envolve dotar as crianças e os adultos de uma compreensão dos princípios e respeito pela liberdade, justiça, democracia, direitos humanos, tolerância, igualdade e solidariedade" (DUPRET, 2002).

- Pós-teste - O pós-teste foi também feito de forma online e colocado no google forms. No pós-teste foi verificado que, $71,4 \%$ dos alunos que o responderam, tiveram 
conhecimento dos concursos e que $85,7 \%$ disseram acreditar que ele possa contribuir com a paz na escola. Um aluno afirmou que "fazer uma boa sempre colabora para paz, não somente na escola, mas no mundo".

Sobre o concurso de música alguns alunos afirmaram: "Um modo de ocupar a mente dos alunos; a música dependendo da melodia é capaz de acalmar alguém”, "porque a música é a melhor arte capaz de unir pessoas" e "de alguma forma, acaba tocando no emocional da pessoa", dentre outras.

\section{CONSIDERAÇÕES FINAIS}

Esta pesquisa, ao lado de seu objetivo principal que foi a contribuição pela paz na escola, gerou um resultado secundário, a criatividade para a sua continuidade, sua realização de forma online. O próprio grupo que planejou e realizou todas as atividades ficava apreensivo e receoso de que algo não desse certo. Mas conseguimos! Acreditase que esta pode ser mais alternativa que a escola poderá utilizar para complementar o seu papel de promover a educação das pessoas.

Portanto, o problema foi respondido, pois foi possível contribuir para a paz com ações dentro da escola; o objetivo foi alcançado, pois desenvolveu-se várias atividades durante o ano, e pós-teste comprovou sua eficiência.

As hipóteses também foram confirmadas, pois muito se conheceu por meio dos alunos, acerca da violência escolar, contribui-se para a cultura da paz e houve mais um ano para corroborar com as conquistas do primeiro ano.

Diretor, coordenador e professores também se envolveram nas atividades. A instituição passava por um momento muito sério de adaptação ao novo sistema de ensino, com aulas online, mas, mesmo assim conseguiu-se obter bons resultados com a pesquisa e criar um novo tipo de ação dentro da pesquisa. As reuniões com o grupo de pesquisa foram realizadas semanalmente via o google meet.

Cabe ressaltar aqui o empenho e seriedade dos bolsistas, tanto quanto no planejamento e execução das atividades, quando nos estudos, uma vez que, a cada semana, havia um texto científico para leitura.

A Lei de Diretrizes e Bases da Educação (LDB/96) enfatiza a necessidade de os professores cultivarem os valores éticos e morais para propiciar oportunidades reais 
para que os alunos estejam permanentemente em busca da construção de sua cidadania. Esta foi a premissa que orientou este trabalho.

Acredita-se que, não apenas o poder público e a sociedade têm que contribuir para a diminuição do problema da violência, mas também as instituições de ensino superior, o que foi feito neste trabalho.

\section{REFERÊNCIAS}

AQUINO, Júlio. A violência escolar e a crise da autoridade docente. Cadernos cedes, ano XIX, n.47, dez. 1998.2 Disponível em: $<$ https://s3.amazonaws.com/academia.edu.documents/33502069/Aquino_-

A_violencia_escolar....pdf?AWSAccessKeyld=AKIAIWOWYYGZ2Y53UL3A\&Expires=1 $\overline{5} 2 \overline{4} 757792 \& \bar{S}$ ignature $=b V W H 1 \% 2 F c 8 k p M k S t L K U X A l f w F p m u l \% 3 D \&$ response-contentdisposition=inline\%3B\%20filename\%3DA_violencia_escolar_e_a_crise_da_autorid.pdf> . Acesso em: 26 abr. 2018.

ARENDT, H. Sobre a violência. Rio de Janeiro: Relume-Dumará, 2009.

ARRIETA, G. A. A violência na escola: a violência na contemporaneidade e seus reflexos na escola. Canoas: ULBRA, 2000.

BRASIL. MEC. Lei de Diretrizes e Bases da Educação 9394/96. Brasília: MEC, 1996.

Juntos pela paz: é tempo de semear. Disponível em:

<http://basenacionalcomum.mec.gov.br/implementacao/praticas/caderno-de-

praticas/ensino-fundamental-anos-iniciais/153-juntos-pela-paz-e-tempo-de-

semear?highlight=WyJlbnNpbm8iLCJwZXNxdWlzYSJd>. Acesso em 30 out. 2020.

CANDAU, V. M.; LUCINDA, M. da C.; NASCIMENTO, Maria das G. Escola e Violência. Rio de Janeiro: DP\&A, 2001.

CARVALHO, José Carlos de Paula. Antropologia das organizações e educação: um ensaio holonômico. Rio de Janeiro: Imago, 1990.

COLOMBIER, C.; MANGEL, G.; PERDRIAUT, M. A violência na escola. São Paulo: Summus, 1999.

CONSTANTINI, A. Bullying: como combatê-lo? São Paulo: Itália Nova, 2005.

CONSTRUIR NOTÍCIAS. Disponível em: <

https://www.construirnoticias.com.br/solidariedade-e-paz/>. Acesso em: 30 out. 2020.

COSTA, J. F. Violência e psicanálise. Rio de Janeiro: Grad, 2007.

DISTRITO FEDERAL. Secretariado Estado de Educação, Currículo da educação básica das escolas públicas do DF, ensino fundamental $5^{a}$ a $8^{a}$ série. Brasília: Subsecretaria de Educação Pública, 2002.

DUPRET, L. Cultura de paz e ações sócio-educativas: desafios para a escola contemporânea. 2002. Disponível em: <https://www.scielo.br/scielo.php?script=sci_arttext\&pid=S1413$8557200200010001>$. Acesso em: 30 out. 2020.

DURAND, Yves. A formulação experimental do AT. 9. In: Revista FEUSP, São Paulo, 14(1), 1980 (trad. Prof. Dr. J. C.de Paula Carvalho).

As estruturas antropológicas do imaginário: introdução à arquetipologia geral.

Lisboa: Presença, 2012. 
PGL.GAL. Educar através da música. Disponível em: <https://pgl.gal/educar-atraves-damusica/>. Acesso em: 30 out. 2020.

ESCOLA INTELIGENTE. Como lidar com a violência na escola? Disponível em: $<$ https://escoladainteligencia.com.br/como-lidar-com-a-violencia-na-escola/ >. Acesso em: 15 set. 2020.

ESCOLAWEB. 10 dicas para prevenir a violência na escola. Disponível em: $<$ https://escolaweb.com.br/artigos/bullying-dicas-prevenir-violencia-escola/>, acesso em: 15 ago. 2020.

ESTADÃO. Cresce violência nas escolas. 2017. Disponível em: <https://opiniao.estadao.com.br/noticias/geral,cresce-violencia-nasescolas,70001949611.amp>. Acesso em: 09 jan. 2019.

FREIRE, A. N; AIRES, J. S. A Contribuição da Psicologia Escolar na Prevenção e no Enfrentamento do Bullying. Psicol. Esc. Educ., Maringá, v.16, n.1, June 2012.

FONTES, M. M. A. Violência nas escolas: a crise da autoridade, Educ. foco, Juiz de Fora, v. 15, 1, p. 77-85, março, 2010.

FOUCAULT, Michel. História da sexualidade: Rio de Janeiro: Graal, 1993.

GOLEMAN, D. Inteligência Emocional, a teoria revolucionária que redefine o que é ser inteligente. Rio de Janeiro: Objetiva, 2011.

GUIMARÃES, E. Escola, galeras e narcotráfico. Rio de Janeiro: URJ, 2008.

JORNAL NACIONAL. Aluno atira em colegas dentro de escola em Goiânia e mata dois, 2017.

Disponível em: <http://g1.globo.com/jornal-nacional/noticia/2017/10/aluno-atira-em-colegasdentro-de-escola-em-goiania-e-mata-dois.html>. Acesso em: 26 abr. 2018.

LOPES NETO A. A.; SAAVEDRA LH. Diga não para o bullying. ABRAPIA. 2004.

LÜDKE, M.; ANDRÉ, M. E. D. A. Pesquisa em educação: abordagens qualitativas. São Paulo: EPU, 2013.

MARCELOS, V. A. A Violência Escolar. 2011. Disponível em: <https://sociologiaresponde.webnode.com.br/news/\%20a\%20viol\%C3\%AAncia\%20esco lar/>. Acesso em: 01 set. 2020.

MINAYO, Maria Cecília de Souza (Org.). Pesquisa Social: teoria, método e criatividade. 18 ed. Petrópolis: Vozes, 2009.

MORIN, Edgar. Introdução ao Pensamento Complexo. Porto Alegre: Sulina, 2015.

SOARES, E. M. do S., TEIXEIRA, L. M. Praticas Educativas e Cultura de Paz:

articulando saberes e fazeres. 2017. Disponível em:

$<$ https://www.ucs.br/site/midia/arquivos/ebook-praticas-educativas.pdf>. Acesso em 30

out. 2020.STELKO-PEREIRA A. C.; WILLIAMS, L. C. de A. Reflexões sobre o conceito de violência escolar e a busca por uma definição abrangente. Temas psicol. vol.18 no.1 Ribeirão Preto, 2010.

WAISELFISZ, Julio Jacobo; MACIEL, Maria. Revertendo violências, semeando futuros; avaliação de impacto do Programa Abrindo espaços no Rio de Janeiro e em Pernambuco I Julio Jacobo Waiselfisz e Maria Maciel. - Brasília: UNESCO, 2003.

ZINATO, V. A. M.; MONTENEGRO. E. Orientações metodológicas de uma pesquisa qualitativa. Brasília: 2004. (texto digitado).

SEKI, N. H.; GALHEIGO, S. M. O uso da música nos cuidados paliativos: humanizando o cuidado e facilitando o adeus. 2009. Disponível em: <https://www.scielosp.org/article/icse/2010.v14n33/273-284/>. Acesso em 30 out. 2020. 
APÊNDICES

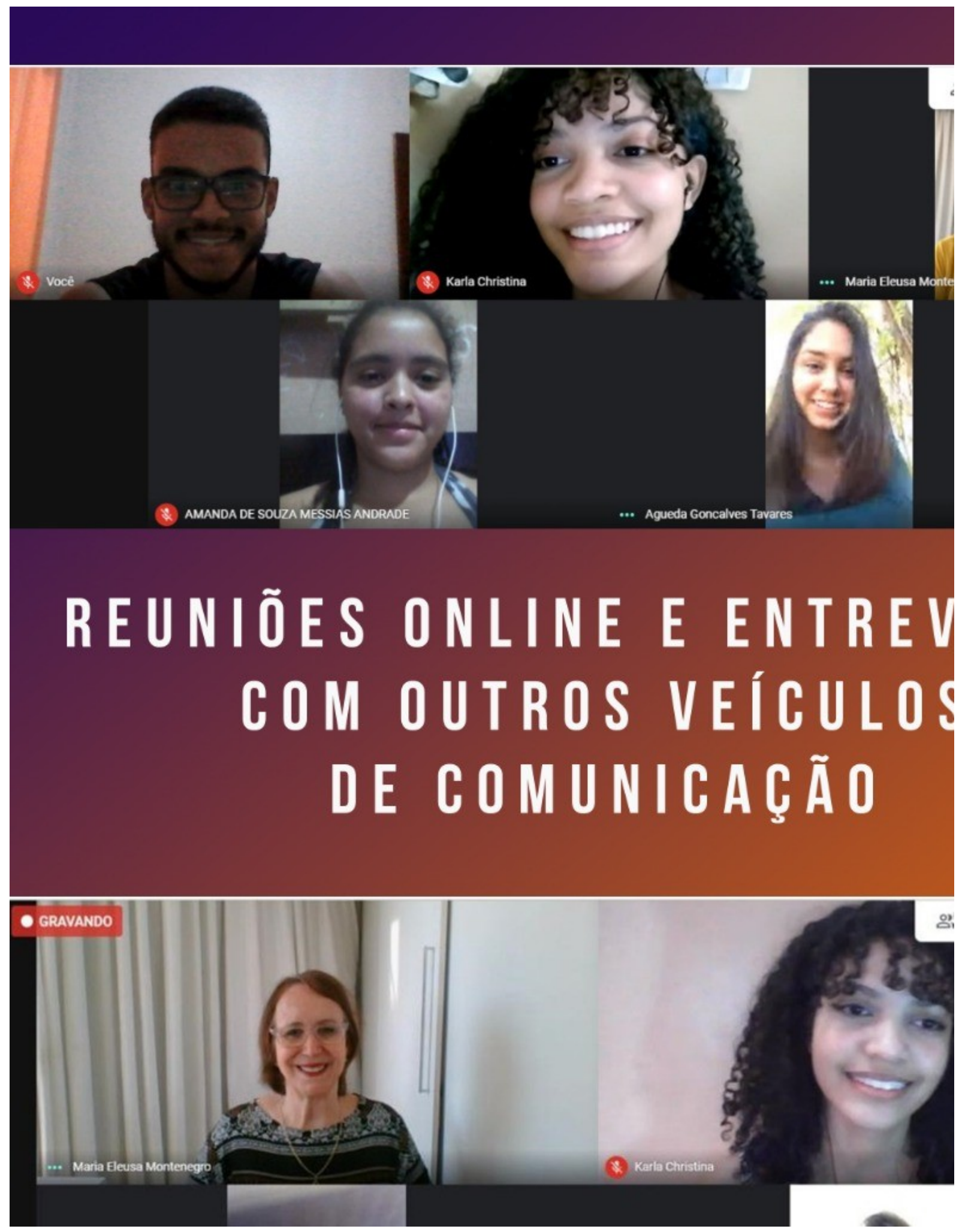




\section{PROJETO

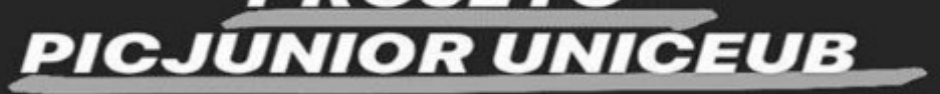

CONCURSO DE MÚSICA GISNO 2020 $01 / 08$

Tema da música: Paz

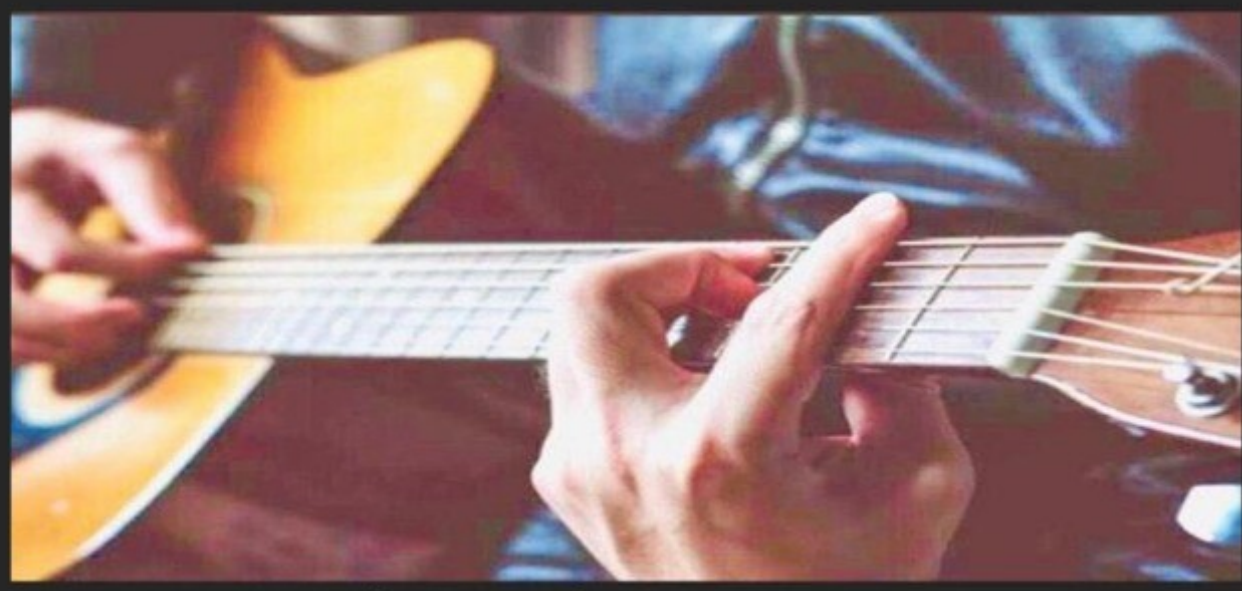

ENVIE SEU VÍDEO ATÉ 31/07 PARA @CONCURSODEMUSICAGISNO

premiação de caixa de bombom para $10,2^{\circ}$ e $3^{\circ}$ Iugar

cante sozinho ou chame um amigo!

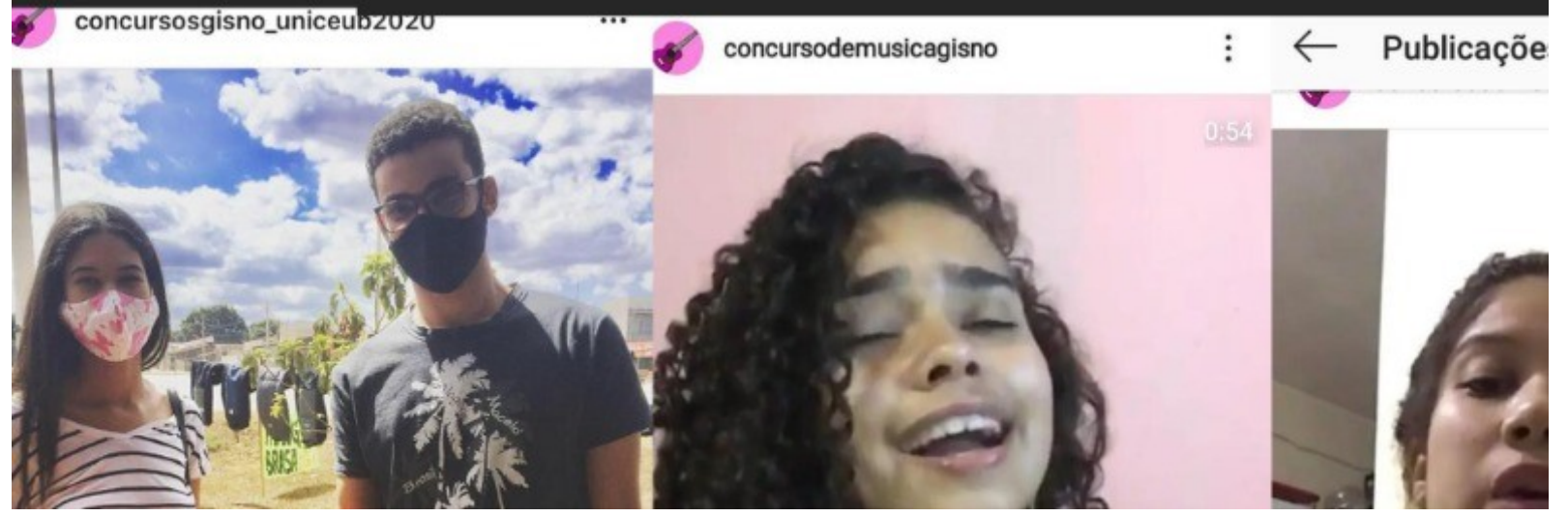




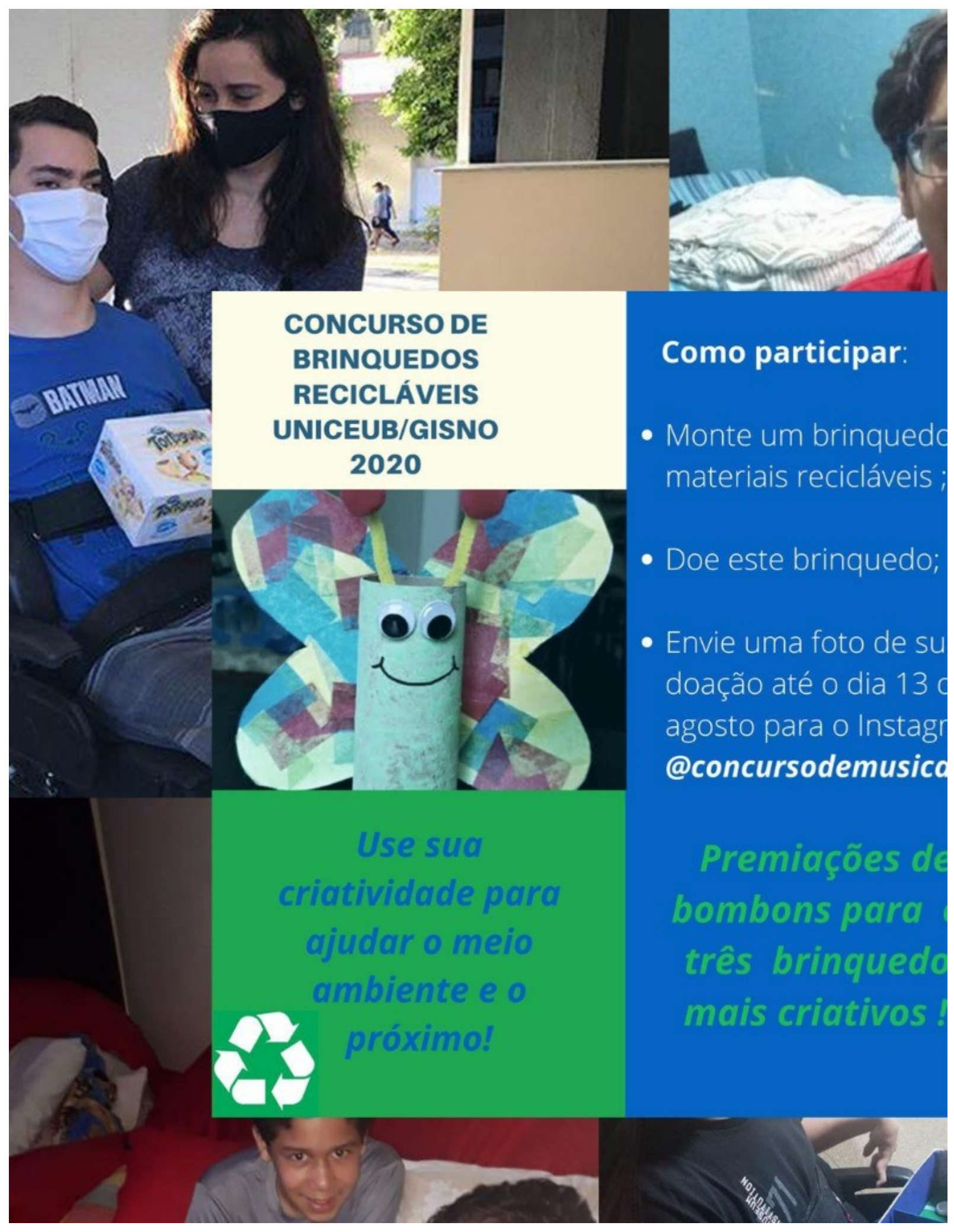




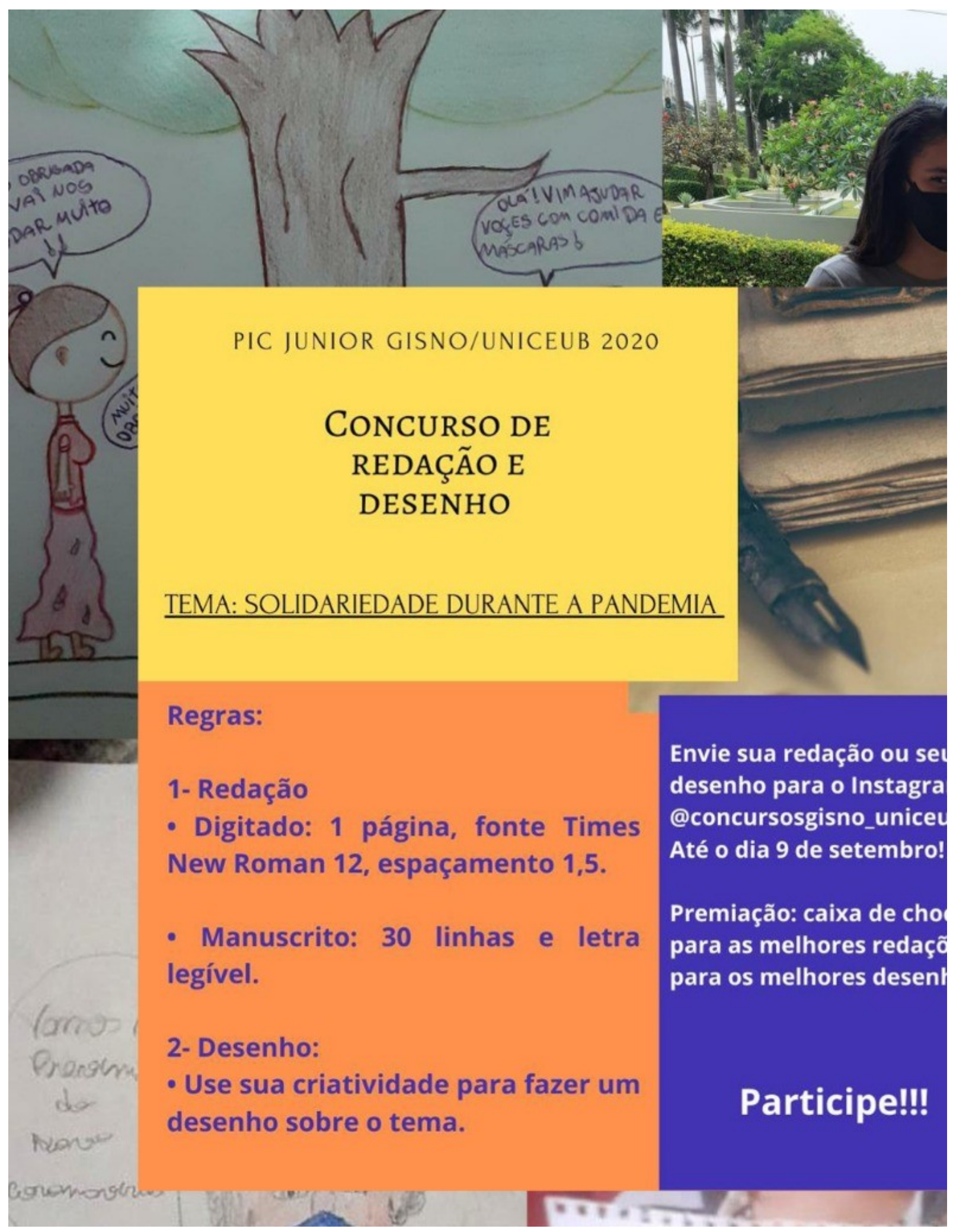




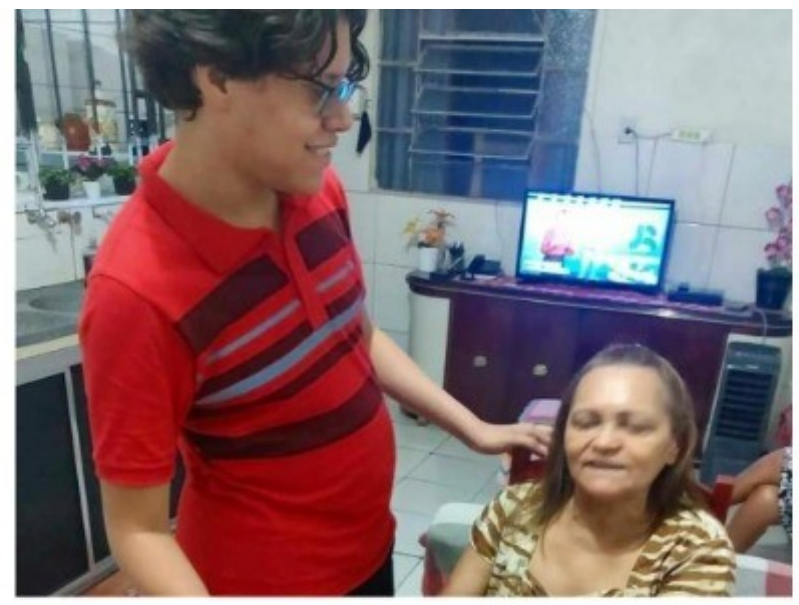

\section{$4^{\circ}$ CONCURSO: BOA AÇÃO UNICEUB/GISNO 2020}

Como participar:

> faça uma boa ação com um colega ou com uma pessoa da terceira idade.

Envie a foto para 0 instagram @concursosgisno_uniceub2020 até o dia 3 de outubro de 2020.

Premiações para os três primeiros colocados!

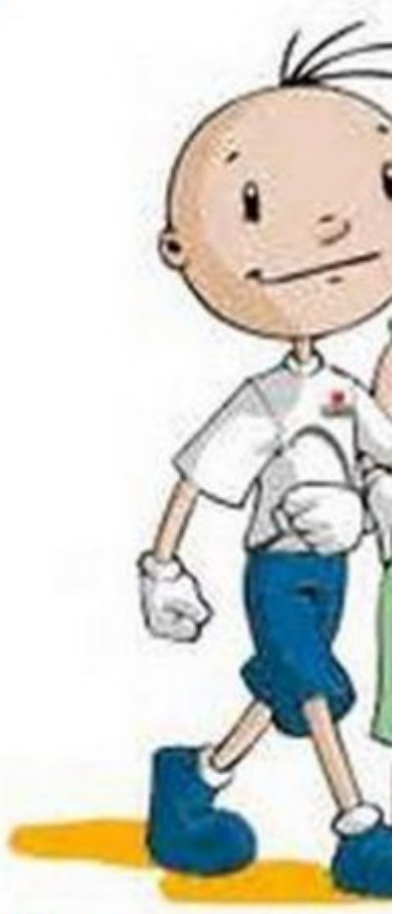

Cada boa ação que você pratica, é uma luz que você ac em torno dos próprios passos.

-Chico Xavier.
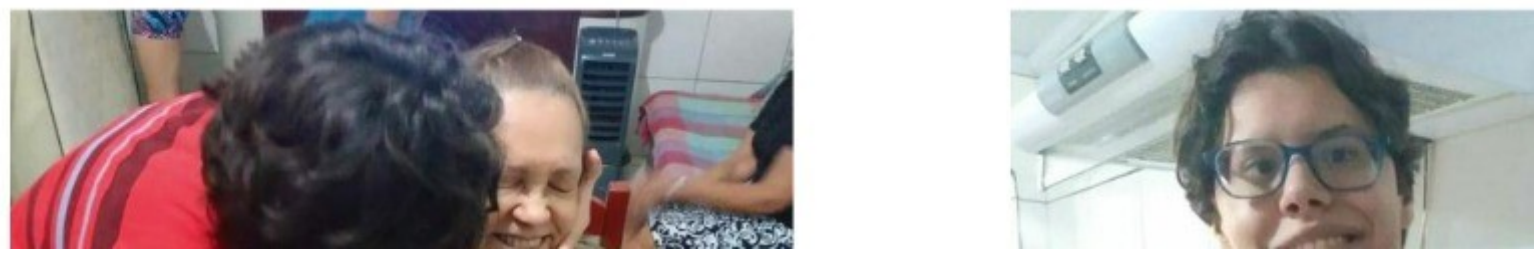